\title{
Estimation of runoff for proposed hydropower stations near Jakobshavn and Christianshåb, West Greenland
}

\author{
Henrik Højmark Thomsen and Roger J. Braithwaite
}

During the winter of 1983-1984 the authors worked together with T. Thomsen and G.H. Jørgensen, Greenland Technical Organization (GTO), to make estimates of runoff conditions for proposed hydropower stations near Jakobshavn (at Pâkitsup akuliaruserssua) and near Christianshåb (at Kûgssûp tasia) (fig. 38). This co-operation was necessary because neither GGU nor GTO had sufficient information to do the job alone. For example, the streamflow in both areas is dominated by runoff from the Inland Ice, and we provided the delineations of the glacier-covered areas (Thomsen, 1984) and estimates of various glacierclimate parameters (Braithwaite, 1984a), together with one year of mass balance data from the area (Thomsen, 1984). On the other hand, GTO had measured the runoff in both areas for the four years 1980-1983 and we benefitted by access to this data. Both groups used climatological data from Jakobshavn, provided by the Danish Meteorological Institute, as a basis for the hydrological calculations. Each group used their own model, i.e. the MB1/SM1/ RO1 models from GGU (Braithwaite, 1984b) and a modified NAM-II model from GTO (Thomsen \& Jørgensen, 1984), and made separate calculations. A summary of the results was sent to the engineering companies responsible for preparing designs of the two hydropower stations. Detailed descriptions of our methods and results are given in Braithwaite \&

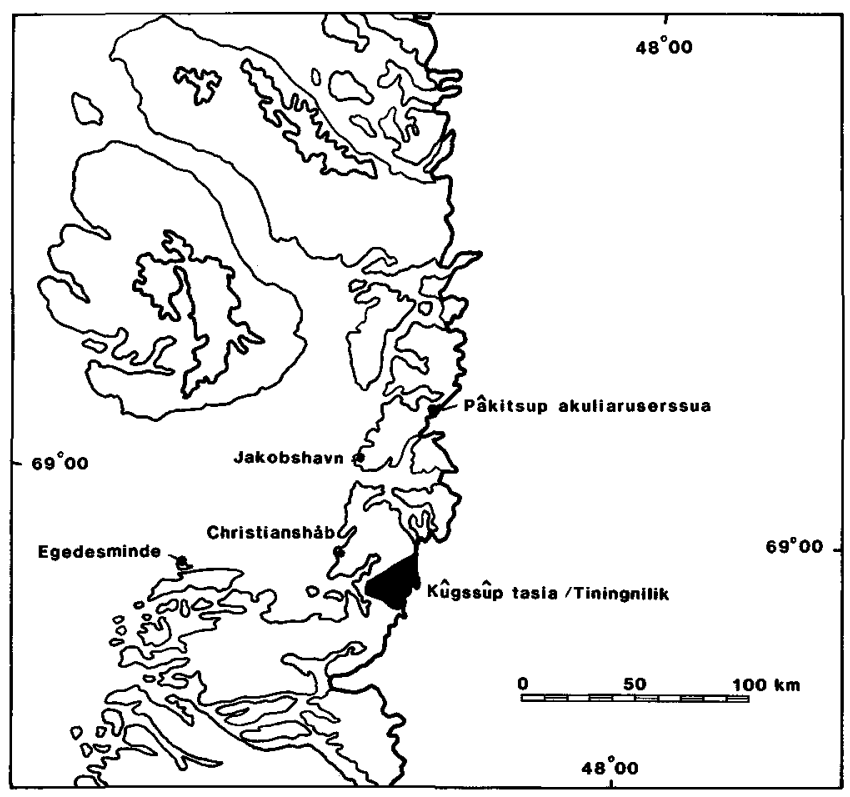

Fig. 38. Map showing locations of the places mentioned in the text. 
Thomsen (1984a,b) and will only be summarized briefly here, especially to illustrate points of principle.

\section{Method}

The volumetric runoff from any basin consists of two separate elements; the areal-distribution of the basin and the runoff per unit area, i.e. the specific runoff. In the GGU approach, the areal distribution of the basin is determined from available maps, supplemented by interpretation of satellite images, while the specific runoff is calculated from temperature and precipitation data by the MB1 and SM1 models, i.e. separately for glacier-covered and ice-free areas. The calculated specific runoff values are then applied to the areal data by the RO1 model which calculates the volumetric runoff. Such an approach can be applied to areas where no runoff measurements are available but the results will not be particularly accurate, although they ought to be good enough for the initial planning of a project. In the present case, four years of runoff measurements (1980-1983) were available, and were used for a final adjustment of the model so that an extended series of annual runoff was calculated for each basin. Such series give a better statistical basis for planning than the short measured series.

Delineation of drainage areas on the Inland Ice was made using topographic maps as well as information from Landsat images (Thomsen, this report). Because of the uncertainties involved, both maximum and minimum estimates of the drainage areas were made, differing in the way in which the subglacial terrain is assumed to affect the drainage pattern.

The specific runoff at any point is calculated from temperature and precipitation data extrapolated from a long-term climate station, in this case Jakobshavn on the coast. The precipitation for each month is divided into separate rainfall and snowfall components according to the probability of above-freezing temperatures. The melting of snow or ice is calculated according to the degree-day principle, i.e. melting is related to the sum of positive temperatures in the month by the degree-day factor. The amount of liquid water, i.e. rainfall plus meltwater, which actually contributes to runoff is determined by allowing it to refreeze within the snow cover, if there is any, until the density reaches a certain critical value. For the present calculations a degree-day factor of $6.3 \mathrm{~kg} \mathrm{~m}^{-2} \mathrm{~d}^{-1} \mathrm{deg}^{-1}$ was used (Braithwaite, 1981) whilst the critical value of density was taken to be that of ice, i.e. no runoff from snow. In order to produce a fair agreement between the model and the one year of mass-balance measurements in the area (Thomsen, 1984) it was necesssary to introduce an extra term representing the warming of the air between the coast at Jakobshavn and the edge of the Inland Ice. For want of anything better, this inland heating effect was assumed to be the same as that at Qamanârssûp sermia (Braithwaite, 1983). The evaporation from glacier-covered areas was assumed to be zero whilst it was assumed to be 20 per cent of runoff for ice-free areas.

\section{Results}

A summary of basin areas and runoff for the two basins is given in Table 4 . The major uncertainty for both basins was the area of glacier cover and three sets of calculations were made; using the areas from the West Greenland Glacier Inventory (Weidick, unpublished) 
Table 4. Overview of measured and simulated runoff at the basins Pakitsup akuliaruserssua, and Kûgssûp tasia

\begin{tabular}{lcc}
\hline Basin & $\begin{array}{c}\text { Pakitsûp } \\
\text { akuliaruserssu }\end{array}$ & $\begin{array}{c}\text { Kûgssûp } \\
\text { tasia }\end{array}$ \\
\hline $\begin{array}{l}\text { Areas }\left(\mathrm{km}^{2}\right) \\
\text { Ice-free }\end{array}$ & 34 & \\
Glacier-covered & $265-788$ & 148 \\
Runoff $\left(M m^{3} /\right.$ year $)$ & & \\
Measured $1980-1983$ & 261 & 241 \\
Simulated $1961-1983$ & $278-320$ & 252 \\
Safe (5\% risk) & $238-294$ & 241 \\
\hline
\end{tabular}

together with maximum and minimum areas from interpretation of Landsat images. It was noticed that there were high correlations between the different series of calculated runoff values and the observed ones, so that uncertainties in the areas could be removed by calibrating the different models against the measured runoff. In both basins, there were periods when the recording instruments failed so that the measured runoff records do actually contain periods when the runoff was estimated subjectively. These estimates were deliberately made on a conservative basis so as not to overestimate the runoff (H.C. Langager, GTO, personal communication). In the case of Pâkitsup akuliaruserssua, we felt that these GTO estimates could be in error so we used the MB1 model to interpolate more objective values, i.e. the model was used to enhance the data. However, we could not be sure about the reliability of this procedure so that two different simulations were made for Pâkitsup akuliaruserssua, one based upon the four years of measurements as provided by GTO and one based upon our enhanced version. This explains why our results for Pâkitsup akuliaruserssua in Ta ble 4 are expressed in terms of a range of values.

For both basins, it was concluded that the runoff for the four years of measurements 19801983 was slightly less than the average for the longer period 1961-1983. However, in view of

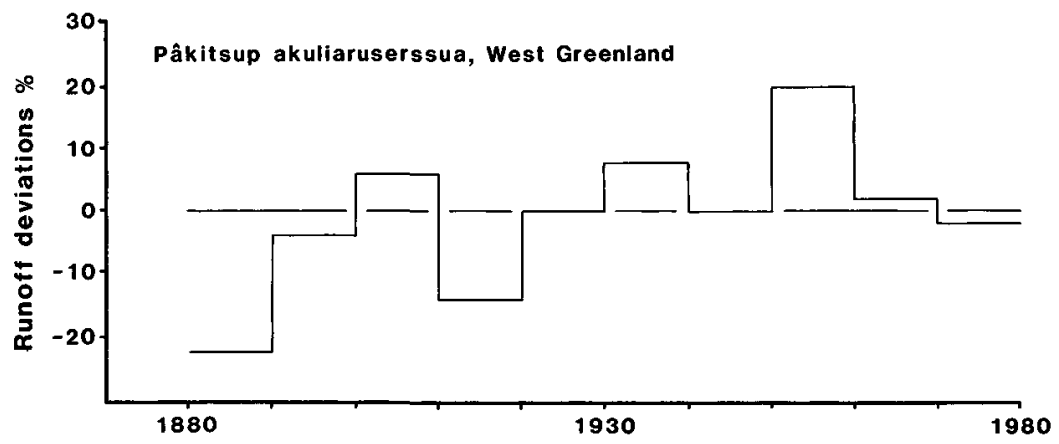

Fig. 39. Calculated variations in runoff at Pâkitsup akuliaruserssua, Jakobshavn, over the past century. Values are expressed as percentages of the 1961-1983 simulated mean annual runoff. 
various uncertainties, and especially the shortness of the period of measurements, a lower value of the runoff must be used for planning purposes. The safe runoff in Table 4 is calculated so that there is only a 5 per cent risk that the true runoff is lower. In order to test the estimates of safe runoff, simulations of runoff were made for both basins for the century 18811980 and an example of the results is given in fig. 39. On a decade-to-decade basis the runoff has varied by about \pm 20 per cent of the average for 1961-1983 but these variations tend to average out over a longer period, e.g. a period of 30 years is often chosen for the planning of hydropower projects. The calculated safe runoff values in Table 4 would have been adequate for any 30-year operating period during the last century.

\section{Outlook}

The period of measurements for runoff in the two basins is still very short and the results will be affected by statistical sampling errors, i.e. the results could be changed as new data become available. There are also several glaciological processes which are still not well understood. The preliminary nature of the work should therefore be emphasized. The present conclusions are that (1) the proposed hydropower projects are reasonably sound from glaciological and hydrological considerations, and (2) data collection should be continued to give more reliable runoff estimates that can be used in the final planning of the projects.

Measurements of runoff and mass balance have now been obtained for a further year 1983/84 by GTO and GGU respectively. A new type of glacier-climate station (Thomsen, this report) in the Pâkitsup akuliaruserssua basin may give improved information on the inland heating effect and degree-day factor for the area. During the winter 1984-1985 the runoff calculations for Pâkitsup akiliaruserssua will be repeated to up-date, and possibly improve, the present results.

Acknowledgements. H. H. Thomsen is supported by the European Economic Community through the EEC European Regional Development Fund. The co-operation of Thorkild Thomsen and Gregors Jørgensen (GTO) is gratefully acknowledged.

\section{References}

Braithwaite, R. J. 1981: On glacier energy balance, ablation, and air temperature. J. Glaciol. 27, 381391.

Braithwaite, R. J. 1983: Comparisons between automatic and manual climate stations at Qamanârssûp sermia. Grønlands geol. Unders., Gletscher-hydrol. Meddr 83/5, 17 pp.

Braithwaite, R. J. 1984a: Glaciological and climatological investigations at Qamanârssûp sermia, West Greenland. Rapp. Grønlands geol. Unders. 120, 109-112.

Braithwaite, R. J. 1984b: Hydrological modelling in Greenland in connection with hydropower. Rapp. Grønlands geol. Unders. 120, 90-94.

Braithwaite, R. J. \& Thomsen, H. H. 1984a: Runoff conditions at Kuussuup Tasia, Christianshåb, estimated by modelling. Grønlands geol. Unders., Gletscher-hydrol. Meddr 84/2, 23 pp.

Braithwaite, R. J. \& Thomsen, H. H. 1984b: Runoff conditions at Paakitsup Akuliarusersua, Jakobshavn, estimated by modelling. Grønlands geol. Unders., Gletscher-hydrol. Meddr 84/3, 22 pp.

Thomsen, H. H. 1984: Glaciologiske undersøgelser i Disko Bugt området 1983. Grønlands geol. Unders., Gletscher-hydrol. Meddr 84/1, 31 pp.

Thomsen, T. \& Jørgensen, G. H. 1984: Hydrological data-work in Greenland. Nordic Hydrol. 15, 3956. 